\title{
DEVIASI GRAMATIKA DALAM TULISAN MAHAHASISWA JURUSAN BAHASA INGGRIS DI STKIP MUHAMMADIYAH BULUKUMBA
}

\author{
${ }^{1}$ IrmaSyahriani, ${ }^{2}$ Kamsina, ${ }^{3}$ AbidinPammu. \\ irma.syahrianiahmad@gmail.com \\ k4msin4ah@gmail.com \\ abidinpammu60@gmail.com \\ ${ }^{1,2,3}$ Program Studi Linguistik, Fakultas Ilmu Budaya, Universitas Hasanuddin, Makassar
}

\begin{abstract}
The reason for conducting this research was based on consideration that university students majoring in English should be at the level where their English is good. Unfortunately, students still made grammatical deviations in both spoken and written form. In this study, 30 students of STKIP Muhammadiyah Bulukumba University enrolled which were taken by random sampling method. This research is aimed to provide useful information particularly as reference for English teachers, lecturers and curriculum developers about grammatical deviations that affects the quality of students' writing composition to minimize it. This research applied the qualitative research to analyze the data. The conclusion of the result shows that the students still have problems in making English sentences. They still make grammatical deviations in their composition. They were also not being able to construct words into sentences and arranged sentences into neat arrangements and coherent paragraphs. Further, syntactical area is the most frequent area where the students committed grammatical deviation. It is proven by the findings that syntax is considered to be more difficult than morphology. It appears that the students' errors distribute to all students' writings. They still make grammatical deviation, but the students do not always make grammatical deviations in the same subcomponent. In terms of difficulties, the students admitted in interview that there are 3 main causes why the students tend to commit grammatical deviation in writing. Those are lack of practice of the target language, lack of source or books that they need, and the last is lack of grammar understanding.
\end{abstract}

Keywords: Grammatical de viation, morphology, syntax.

\section{A. INTRODUCTION}

Grammar is the study of the structure of the language which determines how words arranged into meaningful form units. Studying grammar is one of the most important aspects in a sentence because without adequate understanding of grammar, communication will be confusing. English learners will use broken English and fossilized incorrect patterns and it can communication into a misunderstanding. Learners will not be able to do anything more than uttering separate items of language for separate function.

Nowadays, larger proportions of students have problems in using appropriate grammar item, both in writing and speaking. In their opinion, grammar is the most difficult language item and almost impossible to be understood. Consequently, they are lazy to learn it and eventually they cannot use grammar rules in English and always commit grammatical deviation in producing English especially in writing. Writing is one of skills in English which attracts most students and education. Writing also becomes the most difficult skill for all language users whether the language is the first, second, or foreign language. This is because writing is an extremely complex cognitive activity. 


\section{8 | JURNAL ILMU BUDAYA}

The ability to write in English has been imposed to the students of the English Education Department STKIP Muhammadiyah Bulukumba. They have to learn it from the first semester until the fourth semester. The main purpose of teaching writing for the students was to improve the writing skills. This is because after some years of learning English the majority of students still have difficulties in expressing ideas without grammatical deviation. In addition, the majority of students do not have sufficient knowledge and how to write academic English.

Practically, an error analysis has some contributions to the teaching and learning writing. It provides feedbacks for teachers on the effectiveness of their teaching materials, teaching techniques and it also makes teachers asses more accurate, what remedial works will be necessary for the students to prepare an English language test. Studying the grammatical deviations made by the students, the researcher may be able to reveal the types of grammatical deviation committed by the students. Consequently, studying grammatical deviations also has immediate practical applications for the teachers in which grammatical deviations provide feedbacks. By analyzing students' errors or grammatical deviations, teachers can examine the most common grammatical deviations so that they can decide the ways to treat and minimize deviation.

In relation to the statement above, the researcher is interested to do a research about grammatical deviation in the writing of students of English Education Department at STKIP Muhammadiyah Bulukumba based on linguistic category taxonomy, especially on morphology and syntax.

\section{B. RESEARCH METHODOLOGY Research Design}

This research applied qualitative research. The researcher analyzed and described the writing grammatical deviations committed by students of
English Education Department at STKIP Muhammadiyah Bulukumba. All the data in this research were taken from 5 students' English assignments which collected from the class $\mathrm{C}$ in writing III subject of English Education Department.

The Subject of the Research

The subject of the research was the students English Department of STKIP Muhammadiyah Bulukumba. The population itself was class $\mathrm{C}$ of the fourth semester which is consisted of 30 students. The sample was taken by using random sampling technique where the researcher took only 5 students of the fourth semester of STKIP Muhammadiyah Bulukumba.

\section{Data Collection Process}

In this research, the researcher conducted the research for 2 days. The procedure of collecting data involved the following steps:

Firstly, after collecting the students' compositions, the researcher read them fast in order to know the content. After that, the researcher started identifying the sentence which produced the grammatical deviation, by underlining every part of the sentence such as word, phrase, clause or even the sentence itself. This process is to identify the location of errors in the sentence.

Secondly, after the procedure of data collection is be done, the researcher continued by administering interviewed. The students were interviewed to attain more data about the research itself.

\section{Data analysis Technique}

The data from the task were analyzed by applying grammatical deviations analysis technique, namely analysis grammatical deviations of the students' composition. The analysis of the data was conducted based on two kinds of errors; they are morphology and syntax errors analysis. There are three processes in this research they are identifying, classifying and describing.

In starting the process of data analysis, the researcher identified the 
grammatical deviations that are finding into determining the grammatical deviation type, which are morphological and syntactic errors.

After identifying the grammatical deviations into morphological and syntax as determining the grammatical deviation types, the researcher, then, classified the errors into some specific categories based on Linguistics Category Taxonomies, by using Politzer and Ramirez's model taxonomy. Based on this model of taxonomies, morphological errors in this research are classified into six categories which are indefinite article cases, possessive cases, third person singular cases, simple past, past participle, comparative adjectives or adverbs. While in syntax, there are six main categories of error, which are noun phrases that involve the use of determiner, numbers, pronouns, and prepositions; verb phrases; verbs and verb constructions; word orders; transformation that consist of negative transformation, question transformation and subordinate clause transformation.

Finally, in order to identify types of grammatical deviations committed in the writing compositions of students, the researcher did the process of describing the errors in each category. The last is the data from the interview were analyzed based on the interview guided questions that provided by the researcher.

\section{FINDINGS AND DISCUSSSION}

The data was collected from two resources both from students' assignment and interview. The data is presented to answer the two research questions that the researcher formulated which consists of the type grammatical deviation of morphological and syntax errors, and extent do the grammatical deviation affects the quality of students writing composition.

The data of the research would be shown in the following derived paragraph. Identification of Grammatical Deviation
In this research the researcher identified the grammatical deviation based on the linguistic category taxonomy. Actually, there are five types of linguistic category taxonomy but in this study language component are limited to morphology and syntax.

\section{Grammatical Deviation That Concerns Morphology}

There were some grammatical deviations made by the students based on the types of morphology such as the first composition that is found on sentence 20 he likes to great peoples and he likes to make jokes as well. The correct sentence should be he likes to great people and to make jokes as well.

The second composition is found on sentence 5 she live with her mother. The correct sentence should be she lives with her mother. The third composition is found on sentence 7 Utami Ulandari also an unique person. The correct sentence should be Utami Ulandari is also a unique person.

\section{Grammatical Deviation that Concerns Syntax}

This was a dominant problem in work sheet. The produced sentence can be seen as follows: the first composition is found on sentence 14 she is wearing black skirt. The correct sentence should be she is wearing a black skirt. Next, the erroneous sentence is also found on sentence 17 she is good girl. The correct sentence should be she is a good girl. Found on sentence 25 she is good singer. The correct sentence should be she is a good singer. The erroneous sentence is found on sentence 23 she is easy going person. The correct sentence should be she is an easy going person.

Classifying Types of Grammatical Deviation Based on the Morphology and syntax

\section{a. Grammatical Deviation Based on the Types of Morphology \\ In this case, based on linguistics} taxonomy, there are six morphological 
types, which are indefinite article incorrect, possessive case incorrect, third person singular incorrect, simple past tense incorrect, past participle incorrect and comparative, and the last, adjective/adverb incorrect. The grammatical deviation based on types of morphology can be seen in the following sentence:

1. Incorrect indefinite article

a used for an before vowels for example : in the third composition on sentence 7 she is an unique person. The correct sentence should be she is a unique person.

2. Incorrect third person singular

The first grammatical deviation is concerned with failure to attach $-s$ or es. There were some grammatical deviations committed by the students based on failure to attach $-\mathrm{s}$ or $-\mathrm{es}$. One of them can be seen in the following sentences: in the second composition found on sentence 5 she live with her mother. The correct sentence should be she lives with her mother. Incorrect simple past tense.

The sentence of Omission of $-e d$ is found in the five composition on sentence 8 sometimes I ask him to do something but he just go. The correct should be sometimes I asked him to do something but he did not care for me.

3. Incorrect comparative adjective/adverb

The grammatical deviation of use of more $+e r$ is found in the fourth composition on sentence 9 she is kind than anyone else. The correct should be she is kinder than anyone else.

b. Grammatical Deviation Based on the Types of Syntax

In this case, based on linguistics taxonomy, there are five syntactic types which are noun phrase, verb phrase, verband-verb construction, word order, and some transformation.

1. Noun phrase

The first grammatical deviation is concerned with determiners. Grammatical deviation in using determiners is related to the use of articles. Those kinds of grammatical deviation can be seen in the following sentence: The first one is erroneous sentences found in the first composition on sentence 5. This sentence is she has oval face. The correct sentence should be she has an oval face

The second grammatical deviation is consisted with nominalization. In this study the erroneous sentence of simple verb used instead ing found in the second composition on sentence 6. This sentence is after graduate from Senior High School, we continued our study in the same campus that is STKIP Muhammadiyah Bulukumba. The correct one should be after graduating from Senior High School, we continued our study in the same campus that is STKIP Muhammadiyah Bulukumba.

The third grammatical deviation is concerned with number. There are some types of this study those are: 1 . Substitution of singular for plurals. In this example below, the student misformed the plural noun by omitting plural maker $\{\mathrm{s}\} /$ \{es\}, for example in the second composition on sentence 14 she have thick eyebrow. The correct sentence should be she has thick eyebrows. 2. Substitution of plurals for singular. The sentence of grammatical deviation of substitution of plurals for singular can be seen in the first composition on sentence 10 her teeth is white, the correct sentence should be her teeth are white.

\section{Verb Phrase}

The first grammatical deviation is concerned with omission of to be. In this study, the researcher found several omission of to be such as show omitted in the second composition on sentence 8 sometimes, she angry with me. If she angry, she just silent and like a dumb person. The correct sentence should be sometimes she is angry with me. If she is angry, she is just silent and like a dumb person. 


\section{1 | JURNAL ILMU BUDAYA}

The second grammatical deviation is concerned with replacement of -ing by the simple verb form. The grammatical deviation of replacement of -ing by the simple verb found in the third composition on sentence 4 she always looking incredible. The correct sentence should be she always looks incredible.

The third grammatical deviation is concerned with substitution of the progressive for the simple past. There were some grammatical deviations committed by the students based on substitution of the progressive for the simple past. One of them is found in the third composition on sentence 4 when she was go to the campus, she always looks incredible. The correct sentence should be she always looks incredible when she goes to the campus.

3. Verb-and-verb construction

The first grammatical deviation is concerned with embedding of a noun-andverb construction in another noun-andverb construction. The grammatical deviation in this type is found in the fourth composition on sentence 15 . The sentence is I hope and I want to make her happy and proud of me. The correct sentence should be I hope can be making her be happy and proud of me.

The second grammatical deviation is consisted with omission of to in identical subject construction. In this type the researcher found the grammatical deviation in the first composition on sentence 17 I like play with her because she is good girl. The correct sentence should be I like to play with her because she is a good girl.

The third grammatical deviation is concerned with attachment of the past marker to the dependent verb. The grammatical deviation of attachment of the past marker to the dependent verb is found in the fifth composition on sentence 8. The sentence is sometimes I ask him to do something but he just go. The correct sentence should be sometimes I asked him to do something but he did not care for me.

\section{Word order}

The types of grammatical deviation in this study were repetition of the object. The grammatical deviations found in the first composition on sentences 20. The sentence is he likes to great peoples and he likes to make jokes as well. The correct one should be he likes to great people and to make jokes as well.

The Analysis on the Students'
Difficulties in Constructing English
Sentence

As an attempt to find out students' difficulties in constructing English sentence and the reasons why the students always commit grammatical deviation in their writing, the researcher used interview as an instrument. The aim of the interview was to get more insight into the participants' perception in grammatical deviation when they made composition. The interview questions were structured to focus on their feeling, opinion, and attitudes towards the difficulties they faced in making English sentences.

In terms of the result of the interview, the overall respond shows that students were consistent in thinking that they still difficult to arrange the sentences because lack of grammatical understanding.

To sum up, the result of the interview reveled several important things about the difficulties that students' face in making English sentences when make a composition. 2 points worth noting here are first, the difficulties that students' faces may root from several issues like lack of practice or lack of grammar understanding.

Types of Grammatical deviation Based on Morphology and Syntax.

The first objective of this research is to explain types of grammatical deviation are committed by students. Therefore, an insight to the grammatical deviation itself was considered very 
important to be presented. The explanation below is based on the findings of the description types of grammatical deviation.

a. Types of Grammatical Deviation of Morphology

1. Indefinite article incorrect a used for an before vowels. There are two kinds of morpheme in order to mark indefinite in English, which are $\{a\}$ and $\{a n\}$. The morpheme $\{a\}$ is used before consonant, while $\{\mathrm{an}\}$ is used before the word with the initial of is vowel. In the indefinite article case, the error type occurred is misformation of \{an $\}$ as indefinite article maker. For example, in the third composition on sentence 7 she is an unique person. The correct sentence should be she is a unique person.

The sentence above shows that it displayed the students of grammatical deviation of indefinite article incorrect. Although, the first letter of unique is vowel but the pronunciation it start from initial of consonant. So that, the student is should chose article $a$.

2. Third person singular incorrect

The first grammatical deviation is consisted with failure to attach $-s$ or es. Omission of the inflection is often omitted by the students, as follows: In the second composition found on sentence 5 she live with her mother .The correct sentence should be she lives with her mother. The second is found in the fourth composition on sentence 10 my mother never feel bored and tired to give me advice. The correct sentence should be my mother never feels bored and tired to give me advice.

The example above are grammatical deviation of Failure to attach $-s$ or es because the students did not write the sentences based on English structure in which, verb of simple present tense requires sending $s$, if the subject is the third person singular.

In terms of the second grammatical deviation called the errors of wrong attachment of - s. The grammatical deviation was identified as false concept in which students tended to have misconception of the rules in English that they are currently learning. The example of wrong attachment of $-\mathrm{s}$ is found in the first composition on sentence 20. The sentence is he likes to great peoples and he likes to make jokes as well. The correct sentence should be he likes to great people and to make jokes as well. The sentence of the student applied is false concept of the rules of English. The word of "people" in English is plural so that, this sentence no need to attach of $-\mathrm{s}$.

3. Regular past tense

In the simple past form, bound morpheme $\{$ ed $\}$ is functioned serves as past maker in verb inflection. In this, it is used to mark the verb, which the action happened in the past. For example in the fifth composition on sentence 8 sometimes "I ask him to do something but he just go". The correct should be "I asked him to do something but he did not care for me". In this sentence grammatical deviation of regular past tense made by student. In the fifth composition on sentence 8 the verb "ask" is incorrect. The student should chose verb 2 which is "asked". As we know that, in English structure the verb always became different in any way at all. It is based on the situation.

4. Comparative adjective/adverb incorrect

This type the grammatical deviation appeared mostly in comparative word in which the English grammar of word is subject + to be + more/er + than + object complement. Such grammatical deviation is demonstrated in the fourth composition on sentence 9 "she is kind than anyone else". The correct should be "she is the kinder than anyone else". This sentence is ungrammatical because not follow the rule of English about comparative adjective structure.

Types of Grammatical Deviation of Syntax 


\section{3 | JURNAL ILMU BUDAYA}

\section{Noun Phrase}

The first grammatical deviation is concerned with determiners. In this research, grammatical deviations in using determiners are related to the use of articles. Below is the example of students' commit of grammatical deviation of omission of article. The first is erroneous sentences found in the first composition on sentence 5. This sentence is she has oval face. The correct sentence should be she has an oval face.

The second grammatical deviation is consisted with nominalization. In English Grammar the verb always changing and it can be made misformation occurs in terms of selecting the appropriate word to be used in a particular context. Such grammatical deviation will be explained in sentence such as: The erroneous sentence of simple verb used instead ing found in the second composition on sentence 6. This sentence is after graduate from Senior High School, we continued our study in the same campus that is STKIP Muhammadiyah Bulukumba. The correct one should be after graduating from Senior High School, we continued our study in the same campus that is STKIP Muhammadiyah Bulukumba. This sentence explain that the student chose the word "graduate" while the correct word for that expression is "graduating"

The third grammatical deviation is concerned with number. There are some types of this study such as 1 . Substitution of singular for plurals, in this example below, the student misformed the plural noun by omitting plural maker $\{\mathrm{s}\} /\{$ es $\}$. For example in the second composition on sentence 14 she have thick eyebrow. The correct sentence should be she has thick eyebrows. This sentence show that the grammatical deviation committed by students by substitution of singular and plural type because the word of "eyebrow and student are plural so that, the student should chose "eyebrows'.

\section{Verb Phrase}

The first grammatical deviation is concerned with omission of to be. The "be" as a main verb links the subject and its complement. Greater proportion of students still made grammatical deviation with the omission to be. The rules of the English language applied different "to be" for different subject. The omission of to be is demonstrated such as: The grammatical deviation found in the second composition on sentence 8 sometimes, she angry with me. If she angry, she just silent and like a dumb person. The correct sentence should be sometimes she is angry with me. If she is angry, she is just silent and like a dumb person. The sentence displayed grammatical deviation committed by students of omission of to be. This sentence should to attach to be is.

The second grammatical deviation is consisted with replacement of -ing by the simple verb form. The grammatical deviation occurs when the students need to choose the correct form of verb regarding third person singular or when it comes to choose the most appropriate word that suited a particular context. Such grammatical deviation occurred in the third composition on sentence 4 she always looking incredible. The correct sentence should be she always looks incredible. The misformation also occurs in terms of selecting the appropriate word to be used in a particular context. On sentence 4 that student chose the word "looking" while the correct word for that expression is "looks".

\section{Verb-and-verb construction}

The first grammatical deviation is concerned with embedding of a noun-andverb construction in another noun-andverb construction. The grammatical deviation was identified as false concept in which student is indicated misconcept the rules in English that they are currently learning. This type of grammatical deviation is indicated to be result of partial exposure of the target language itself. The 
grammatical deviation can be seen in the fourth composition on sentence 15. The sentence is I hope and I want to make her happy and proud of me. The correct sentence should be I hope can be making her be happy and proud of me.

The second grammatical deviation is consisted with omission of to in identical subject construction. We can see the findings many students committed grammatical deviation of omission of to when made construction in a sentence. Those type of grammatical deviation such as in the first composition on sentence 17 I like play with her because she is good girl. The correct sentence should be I like to play with her because she is a good girl. The sentence above show that some students still difficult made a sentence by used construction to in a sentence. It is can be happened because lack of grammar understanding.

\section{Word Order}

The last is grammatical deviation of word order, in this type the grammatical deviation appeared to repetition of the object and it is dissipation of the word. Such grammatical deviation will be explained such as: in the first composition on sentences 1 he likes to great peoples and he likes to make jokes as well. The correct one should be he likes to great people and to make jokes as well.

Grammatical Deviation that Affect the Quality of Students' Writing.

The second objective of this research is to explain the extent of the grammatical deviation affects the quality of students writing composition. Furthermore, the data was taken by the researcher by collecting students' assignments and doing interview too.

Grammatical deviation are considered as the inevitable consequences of language learning, it is a part of the language learning that cannot be separated from the learning itself. Grammatical deviation is viewed as more systematic and occurs all the time without the students' realize. From the findings above, it is show that all students still committed grammatical deviation in their writing because lack of grammar understanding. Consequently, they are still hard to express their idea without grammatical deviation. They are not able to construct the words into sentences and arrange the sentences into neat arrangements and coherent paragraphs.

\section{CONCLUSIONS}

The $5^{\text {th }}$ semester students of STKIP Muhammadiyah Bulukumba still have problems in their writing. They could not use grammar rules accurately and always committed grammatical deviation in writing which produced low quality of writing product. They are also not being able to construct words into sentences and arranged sentences into neat arrangements and coherent paragraphs. By the investigating from their composition, syntactical area is the most frequent area where the students committed grammatical deviation. It means that syntax is considered to be more difficult than morphology.

In terms of difficulties, the students admitted from interview that there are many reasons why the students always commit grammatical deviation in writing such as lack of practice of the target language, less of source or books that they need, and the last is lack of grammar understanding.

It is essential that analysis of grammatical deviation needs to be introduced and taught to the students from the earlier level as possible. Beside that, the lecturer have to give motivation and always try to find the best method in learning process to make the students more interest to practice their English such as give more handwriting exercise and after that give correct about their mistake or their ungrammatical. There is a need to encourage greater amount of practices both inside and outside classroom to strengthen thin proficiency. 


\section{BIBLIOGRAPHY}

Armenakis, A. A., Harris (1993). Creating Readiness or Organizational Change. Human Relations.

Brown, H. Douglas. 2000. Principles of Language Learning and Teaching. (third edition). New Jersey: Prentice Hall.

Brown, H. Douglas. 2000. Principles of Language Learning and Teaching. (third edition). New Jersey: Prentice Hall. 2001. Teaching by Principles: an Interactive Approach to Language Pedagogy 2nd ed. New York: Pearson Education.

2004. Language Assessment: Principles and Classroom Practices. London: Pearson Education. 